\title{
Effects of Business to Business Relations on Customer Satisfaction and Loyalty in the Context of a Developing Country
}

\section{Gülşen Akman, Bahadır Yörür}

Department of Industrial Engineering, Kocaeli University, Kocaeli, Turkey.

Email: akmang@kocaeli.edu.tr, bayorur@kocaeli.edu.tr

Received April $4^{\text {th }}, 2012$; revised May $4^{\text {th }}, 2012$; accepted June $4^{\text {th }}, 2012$

\begin{abstract}
In the supply chain context, effective business to business (b2b) relationships are of core importance for companies to enhance their own ability to be more competitive in the marketplace, to create competitive advantage and to achieve mutual goals. Therefore, the focus of this research is customer satisfaction, customer loyalty and affecting factors of satisfaction and loyalty in manufacturer/supplier relations in the $b 2 b$ context. This paper defines dimensions of $b 2 b$ relationships between manufacturers and their suppliers, and then proposes effects of these dimensions on customer satisfaction and loyalty. Study is performed in the metal industry in a developing country, Turkey. Collected data is analyzed by Structural Equation Modeling (SEM) Methodology, and finally results are presented and discussed.
\end{abstract}

Keywords: b2b Relations; Satisfaction; Loyalty; Structural Equation Modeling; Turkey

\section{Introduction}

Close and strong relationships between manufacturers and their suppliers in business markets are getting more and more important to gain a competitive advantage in the market and to achieve business goals. Therefore, in recent years, the purchasing/supply function has been seen as a key strategic tool for firms to achieve their competitive advantage and a strategic part of a value chain that extends from the supplier to the end-customer [1].

According to Skarmeas et al., strong relations with suppliers provide to manufacturing companies to achieve supply sustainability, minimize risks of new exchanges, and help in inventory level and inventory cost reduction [2]. Close relations with suppliers can evantauate in shorter cycle times, less quality defects, reduced costs, and streamlined processes [3].

Nowadays, from manufacturers' perspective, customers have more impact on purchasing and bargaining power. In this regard, manufacturers need to cooperate with their suppliers to increase profitability and to maximize the productivity at the minimum cost [4]. Therefore, today, manufacturer-supplier relationships are more and more important to be competitive, productive and profitable. Proper management of supplier relationships comprises one require element of supply chain success [5].

Specifically, in emerging countries such as Turkey, attention should be given to buyer-supplier relations to survive in global and intensive competitive environments and to compete with global rivals. Specifically, customer satisfaction and loyalty are two key constructs in business-to-business (b2b) relations. In this context, a paradigm is acceptable, and a general theme of this paradigm is the changing attention from short-term exchanges to long-term relationships with key customers or key suppliers [6]. Some firms maintain arm's-length relationships with their suppliers and use competition and supplier switching as motivations to provide optimal performance from their supply base. In a b2b environment, suppliers need to understand the nature and circumstances of their customers due to the unique characteristics of the customers acting as organizations [7]. When the studies in the literature are investigated, it can be seen that most of these studies were generally performed in developed countries such as Norway, UK, Australia, USA, Spain, and Japan. There is very little study carried out in developing countries in the literature such as India. For this reason, in order to make a contribution to literature from this point this study is carried out in a developing country, Turkey.

This study aims to add to the literature and provide a picture of how dimensions of relationship influence customer satisfaction and loyalty in a b2b context in a developing country. Thus this paper undertakes to enrich 
the research focused on $\mathrm{b} 2 \mathrm{~b}$ relations as a multidimensional concept defined by four components (trust, commitment, communication, and also cooperation), and their effects on customer satisfaction and loyalty. We use the metal manufacturing industry in Turkey as a sample to test our hypotheses and choose to survey small and medium enterprises (SMEs) and measure their loyalty, perceptions of satisfaction, trust, communication, commitment, and cooperation. We explore the contribution of dimensions of $b 2 b$ relationship to measure of customer satisfaction and customer loyalty, and investigate the $b 2 b$ relationship construct through the power of its four proposed dimensions, trust, commitment, communication, and cooperation.

The rest of the paper is organized as follows. First, the relevant literature is reviewed to provide some behavior to each construct we propose in this study. Second, the conceptual model and research hypotheses are developed. Third, the research methodology is described. Collected data is analyzed by Structural Equation Modeling (SEM); and results are presented. Finally, the paper concludes with a discussion and conclusions with managerial implications in order to improve b2b relationship satisfaction and enhance customer loyalty for $\mathrm{b} 2 \mathrm{~b}$ customers, and provides the limitations of the research and suggestions for future research.

\section{Literature Research}

In this study, a supplier is defined as "any company who provides goods, materials, or services to a company to convert them to a product". A supplier often manufactures storable items, and sells those items to a customer. Customer/buyer is defined as "a manufacturer which converts a product from one form to another" [8].

In the business research literature, inter-firm relationships have attracted great attention over in the last decades. Specifically, increasing of interdependence between firms and their suppliers have been expanded the importance of inter-firm relationships in the $b 2 b$ context. To develop a few but selective, stable and long term relationships between buyer/manufacturing firms and their suppliers has been a main theme in the studies such as Ganesan [9], Bello et al. [10], and Hewett et al. [11]. The relationship with the supplier is considered as a partnership, and it is valuable to the buyer firm as it can be a source of competitive advantage and an important and critical factor to develop and to maintain a sustainable competitive advantage for the manufacturing firms [12, 13]. Buyer-supplier relationships are relations between buyer and suppliers have also been emphasized with themes such as partnership, outsourcing, strategic alliances and supply-chain cooperation and collaboration [1].
According to Walter et al., the success or failure of a supply-chain-alliance is determined by the level of commitment, trust, and cooperation between its members [14].

Selnes analyzed effects of competence, communication, commitment and conflict handling on trust and satisfaction via enhancement and continuity of the relationship in Norway [15]. Jonsson and Zineldin determined critical variables such as communication, adaption, reputation, coercive power, non-coercive power, cooperation, relationship bonds, dependency, relationship benefits, and then investigated their effects on satisfaction in Swedish material/products dealers sector [16]. Dapiran and Hogarth-Scott used dependence, power and cooperation as dimensions of the relationship between food retailer and their suppliers in UK and Australia [17]. Wo and Ennew studied influences of atmosphere, adoption, cooperation, service quality, customer satisfaction and behavioral intention on relationship quality [18]. Trevatanawong and Quazi (2006) investigated effects of trust and power on cooperation with moderating effects of distance and collectivism, individualism [19]. Vasudeven et al. studied influences of satisfaction and relational switching cost on commitment in Hong Kong and Indian Manufacturing sector [20]. Trevatanawong et al. studied rational constructs such as total interdependence, trust, supplier commitment, cooperative norms and conflicts and their effects on relationship satisfaction in relationship phases of build-up, maturity and decline in importers of Tai products in Australia [21]. Kingshott and Pecotich researched effects of psychological contracts and violation on trust and effects of trust on commitment between Australian suppliers and distributors [22]. Rodriguez et al. studied effects of communication, cooperation and conflict on satisfaction, effects of cooperation, conflict and satisfaction on trust, effect of trust on performance in Spanish food, chemistry, and plastic ironsteal sectors [23]. Kabadayi and Ryu determined trust, monitoring, information sharing and performance as characteristics of the relationship and determined influences of trust, monitoring, and information sharing on supplier performance in American textile, metal, steel, and electronic industries [24]. Chung et al. investigated effects of trust, dependency, conflict and performance on customer satisfaction in the context of retailer-buyer-supplier relations in Japan [25]. Svensson et al. examined Norwegian manufacturer-supplier relationships and tested the measurement and structural properties of a model where trust and commitment are positive precursors to satisfaction and satisfaction is a positive precursor to coordination, cooperation, and continuity [26]. We sum up the literature of relationship dimensions, it seen that some dimensions of buyer-supplier relationships were used more 
frequently than others. For example, trust, cooperation, dependency and commitment are most used dimensions. Knowledge sharing, collaboration, autonomy, atmosphere, contribution, distance are rarely used dimensions of relationship.

When the studies mentioned above are investigated, it can be see that most of them were generally carried out in developed countries such as USA, UK, Australia, Spain, Japan etc. In the literature, there is a few study performed in developing countries. Therefore, the study is performed in a developing country, Turkey, and the most used dimensions are selected for this research. In this study, buyer-supplier relations is defined as buyer firms' perceptions of the supplier firm's behavioral and operational relationship characteristics such as supplier's trust, communication, cooperation, commitment. These characteristics are called dimensions of buyer-supplier relationships. Also these characteristics are increasing customer satisfaction and expanding customer loyalty.

\section{Concepual Model and Research Hypothesis}

Based on the previous discussion and literature review, the conceptual model is developed as shown in Figure 1. The conceptual model positions relationships between dimensions of buyer-supplier relations and customer satisfaction, and additionally the model shows satisfaction as a positive mediator between loyalty and dimensions of $\mathrm{b} 2 \mathrm{~b}$ relations in a developing country, Turkey. All of the paths are hypothesized to be positive in Figure $\mathbf{1}$ and the specific hypotheses are discussed as follows.

In the b2b context, some evidence shows that relationship components influence customer satisfaction and loyalty [7]. In the following, there are some prepositions related with effects of relationships elements on customer satisfaction and loyalty in the context of b2b relationships. These elements are trust, communication, cooperation and commitment. These elements are determined according to characteristics of supplier- buyer relations in Turkey. Listed below are seven hypotheses formulated to

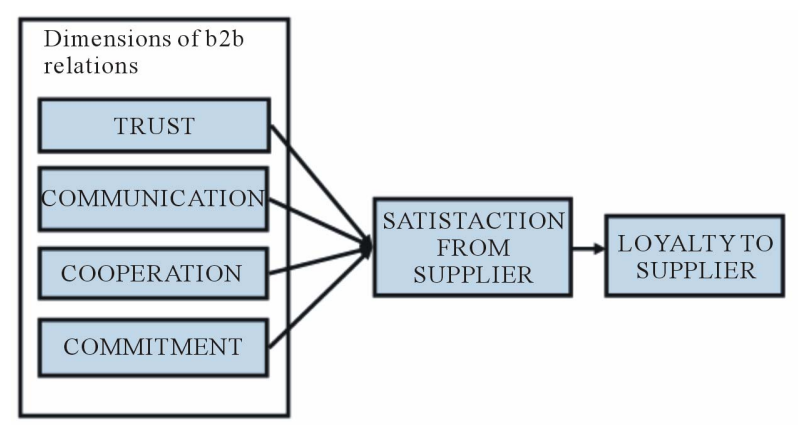

Figure 1. Conceptual model of the study. address customer satisfaction and loyalty issues identified by a synthesis of the existing body of research examined earlier in this paper.

Customer loyalty. Loyalty is a construct that captures the essence of a business customer's desire to continue doing business with a given supplier in relation to others in the evoked consideration set [27]. Creating a loyal b2b customer base is about maintaining numbers of customer overtime and it is also about developing the relationship with business customers to maintain purchasing in the future. If a supplier is equipped with the knowledge of their business customers' loyalty levels, it will be able to figure how their efforts to maintain good relationships can contribute to its profit levels [7]. In this study customer loyalty is defined as a strong sense of loyalty to the supplier, expecting of the supplier to be working with firm for a long time and maintaining a long-term relationship with the supplier.

Customer satisfaction. In the context of inter-firm relationships, satisfaction refers to a positive state resulting from the appraisal of all attributes of a firm's working relationship with another firm. Customer satisfaction is defined as a customer's overall evaluation on the expected and perceived performances of the supplier. If the perceived performance meets or exceeds the expectations of the customer, the customer is satisfied; otherwise, customer is dissatisfied [28]. Satisfaction with supplier relationship is viewed as a positive opinions resulting from the appraisal of all aspects of a firm's working relationship with supplier. For many supplier firms, establishing and maintaining a long-term relationship with satisfied buyers is critical and important to long-run survive. In b2b research, several authors show the existence of a link between satisfaction and loyalty. For example, Eriksson and Vaghult found that satisfied customers stay with the firm. Their results show that as relationship satisfaction increases, so does customer retention [29].

There is a strong link between satisfaction and loyalty toward a supplier or product [30]. Heskett el al. proposed that satisfaction is a key determinant to each level of brand loyalty and it is an important variable in explaining loyalty [31]. According literature customer satisfaction has a significant and positive effect on customer's attitudes and future purchase intentions. In general cases, developing individual relationship with business customers offers supplier a secure loyal customer base and opportunities to reach a high level of profitability. Because of that business customers spend large amounts of money in their purchase of products and services, managing and maintaining loyal business customers can offer greater income for a supplier [7]. These findings provide the theoretical basis for our following hypothesis.

H1. Customer satisfaction increases buyer's loyalty to 


\section{suppliers}

Trust. Trust is one of the most critical factors in buyer-supplier relationships, and is an important element in defining the strength of the relationship. The trust is essential to sustain long-term relations, and it is defined as the willingness to rely on an exchange partner in whom one has confidence [32]. Gao et al. stated that, "buyers' trust to suppliers is established when buyers believe in the suppliers' willingness to keep their promises and their ability to deliver competent and need-satisfying performance" [33]. When buyers perceive suppliers to be benevolent and consistent, they become less worried about being taken advantage of by the suppliers. Trust plays an important role to improve supply chain responsiveness [34]. The trust in the supplier firm's honesty, credibility, and benevolence may build up fair satisfying interactions between the buyer and supplier, and prevent conflicts from leading to dissatisfaction through the recognition of supplier firm good faith [25]. When a manufacturer's trust in a supplier is high, the manufacturer has a great desire to ensure the relationship's success. Therefore, the manufacturer is willing to invest time, effort, and money in the relationship [10]. As a result, satisfaction from supplier increases.

H2. Buyer trust to supplier influences customer satisfaction positively

Cooperation. Cooperation can be determined as the initiation and participation in collaborative arrangements with its buyers and suppliers in a firm's environment [35]. Cooperation from buyer perspectives defined as that firms' perceptions of degree to which suppliers work together to solve problems, establish strategic directions and achieve their reciprocal goals [36]. From a b2b perspective, cooperation contains the coordination tasks which are undertaken jointly and singly to pursue mutual goals and activities undertaken to develop and maintain the relationship [18]. Strong partner relationship is consistently thought as crucial to successful supply chain collaboration. It increases the cooperative actions like that firms exchange critical information and work together to plan and implement new supply chain strategies. Thus companies share the risks and rewards along the way $[37,38]$. For b2b relationships, specifically, customer satisfaction has been found to lead to desirable outcomes such as cooperation and long term orientation. Anderson and Narus [39], Ganesan [40], Mohr and Speakman [41] demonstrated a positive relationship between cooperation and satisfaction. The firms' cooperative efforts cause to a greater efficiency and to the achievement of higher levels of customer satisfaction [5]. Therefore an effective cooperative relationship affects customer satisfaction.

H3. Cooperation influences customer satisfaction po- sitively

Communication. Communication is the exchange of information between supplier and customer [15]. Effective communication has been defined as the formal and informal sharing of meaningful and timely information between a buyer and a supplier and it has been closely linked with performance outcomes [23]. Communication efforts between buyer and supplier involve many interorganizational contacts and exchange of information takes place frequently and informally. Part of the open communication between manufacturing companies and their suppliers is that manufacturing companies should provide suppliers with feedback about the results of their evaluation of suppliers and the mistakes that supplier done [13]. Open communications means that suppliers communicate openly, sincerely, and substantively with customers formally or informally [42]. Then communication increases customer satisfaction. The extant literature suggest to importance of communication in the increasing a supplier performance and customer satisfaction. For example, numerous authors such as, Anderson and Narus [39] and Morgan and Hunt [43], emphasize the importance of communication in developing and maintaining a b2b relationship. Selnes stated that "because satisfaction is an evaluation of an outcome compared to some norm, communication is expected to be an important source for satisfaction because it can lead to a shared understanding of performance outcome and expectations" [15]. Therefore communication influences buyer's satisfaction from supplier.

H4. Communication influences customer satisfaction positively

Commitment. Commitment can be defined as a partner's desire to develop a stable relationship and a willingness to make short-term dedication to maintain the relationship [44]. It means the degree to which suppliers feel obligated to maintain working with the buying firm [36]. According to Moorman et al., commitment is defined as the "enduring desire to maintain a valued relationship" with partners such as suppliers and customers [32]. For this study, supplier' commitment is defined as the manufacturing firms' perception of the degree to which supplier firm feels pledged to continue business with the buying firm. This contains loyalty of suppliers to the buying firm, willingness to make investment in the buying firm's business and reliance on the stability of a long-term relationship. It is resulted in increased customer satisfaction. Jap and Ganesan [44] found that commitment of firm to work together with suppliers enhances the perception of agreement, along with the possibility of providing better quality products, and thus it results in higher partner satisfaction. Liu et al. reveals the complex relationship between calculative commitment 
and economic satisfaction [45]. Commitment helps the supply chain channels to operate efficiently and to improve the economic conditions of supply chain members, and thus it helps to have a close relationship with satisfaction. Farrelly and Questar expressed that "It seems logical to argue here that trust and commitment are key factors of satisfaction, a more general concept and a closer determinant of their decision to extend, renew, or terminate the sponsorship relationship"[46]. Relationship between a manufacturer and its supplier should present evidence that a high level of commitment results in higher level of satisfaction with the relationship.

H5. Commitment of supplier influences customer satisfaction positively

\section{Methodology and Research Design}

\subsection{Sampling Frame}

This research was performed in the metal manufacturing industry in Kocaeli in Turkey. Metal industry thrives on strong customer-supplier relationships. Because of the capital-and process-intensive nature of metal manufacturing, most manufacturers require reliable suppliers. This will help their scheduling and productivity. Besides, metal manufacturers themselves produce capital goods which require capital goods as inputs. Thus, the sector is such that customer and suppliers often have to relate closely.

Metal industry incorporates many different manufacturing, and it includes all kinds of construction materials, hand tools, kitchen tools manufactured from ferrous and non-ferrous metal materials. It also contains activities forging, pressing, covering and processing all kinds of metal [47]. Metal industry is an important intermediate goods manufacturer sector in Turkey. Relationships between suppliers and customers are developing in the sector. Some processes traditionally performed by customers are performed by suppliers anymore. For example, an input used for manufacturing a refrigerator is demanded as sliced, formed and painted by customers [48]. There are 1843 firms which are members of Kocaeli Chamber of Industry. 293 of these firms are performing in the metal industry in Kocaeli. $78.9 \%$ of these firms are small sized enterprises, $15.4 \%$ of them are medium sized, and $5.7 \%$ of them are big sized [49].

\subsection{The Characteristics of the Sample}

For the aims of the study, a questionnaire was developed. The questionnaire consists of two parts. First part includes general information about characteristics of the firms and respondents. Second part consists of 16 question related with $b 2 b$ relationships, satisfaction and loy- alty. These 16 questions are developed based on previous measures in the literature. Data was collected from buyers with the referred as a main supplier performing in the metal industry. An e-mail survey was conducted. Firstly, 293 questionnaires were sent via e-mail to managers of manufacturing firms performing in Metal industry in Kocaeli region in Turkey. One month later, after having being sent e-mails, a reminder e-mail was sent to managers of the firms. A total of 175 questionnaires was collected, in which, 7 questionnaires were ineffective because they are incomplete. Therefore, a total of $168(57 \%)$ effective questionnaires were collected. Some characteristics of firms and respondents are presented in Table 1. Most of the firms are SME $(27 \%+38 \%+14 \%+17 \%=$ $96 \%$ ) according to total employee number.

Most of the firms are small sized $(27 \%+38 \%=65 \%)$. $14 \%+17 \%=31 \%$ of the firms are medium sized, and $4 \%$ of them are big sized. $19 \%$ of the firms have performed for less than five years. $49 \%$ of the firm have performed for less than 15 years and more than five years. $31 \%$ of them have performed for more than 15 years.

\subsection{Measures and Reliability Test}

All measurement items were either adapted from previous research because of that previously tested and validated, or developed specifically for this study. Table 2 contains detailed measurement items for each construct and their sources. Overall, all constructs in the model were measured with multiple-item scales. The guideline

Table 1. Some characteristics of companies.

\begin{tabular}{lccc}
\hline Item & & QTY & $\%$ \\
\hline $01-25$ & 45 & 27 \\
$26-50$ & 64 & 38 \\
Total number of employee & $51-100$ & 23 & 14 \\
& $101-250$ & 29 & 17 \\
& $251-500$ & 5 & 3 \\
& 501 and upper & 2 & 1 \\
& Total & 168 & 100.0 \\
& $0-2$ & 5 & 3 \\
& $2-5$ & 27 & 16 \\
& $6-10$ & 49 & 29 \\
& $11-15$ & 34 & 20 \\
& $16-20$ & 24 & 14 \\
& 21 and upper & 29 & 17 \\
& Total & 168 & 100.0 \\
\hline
\end{tabular}


Table 2. Measurement items.

\begin{tabular}{|c|c|c|}
\hline & Item & Sources \\
\hline \multirow{3}{*}{ Trust } & Tr1. We believe that this supplier care themes important for us & Morgan and Hunt [43] \\
\hline & $\operatorname{Tr} 2$. Generally speaking, this supplier is trustworthy. & Ganesan [40]. \\
\hline & $\begin{array}{l}\text { Tr3. When making important decisions, this supplier considers } \\
\text { our best interests as well as its own. }\end{array}$ & Humphreys et al. [54] \\
\hline \multirow{3}{*}{ Cooperation } & Co1. We are in a cooperation with this supplier in design facilities & \\
\hline & Co2. Our firm tells this supplier openly on our strategic plans and goals & Prahinski and Benton [36] \\
\hline & Co3. This supplier often shares confidential information with our firm. & \\
\hline \multirow{2}{*}{ Communication } & Com1. There is an open communication between our firm and supplier. & Lancastre and Lages [55] \\
\hline & Com2. This supplier is accessible to communication & Humphrey et al. [54] \\
\hline \multirow{3}{*}{ Commitment } & $\mathrm{Cm} 1$. This supplier is willingness to make long term investments that provide utility to us & \\
\hline & $\mathrm{Cm} 2$. Our relationship with the supplier is a long-term partnership. & $\begin{array}{l}\text { Lancastre and Lages [55] } \\
\text { Humphreys et al. [54] }\end{array}$ \\
\hline & $\mathrm{Cm} 3$. This supplier is willingness to dedicate all resources to satisfy our firm. & \\
\hline \multirow{2}{*}{ Customer Satisfaction } & Sa1. We are fairly satisfied with business relationship with the supplier & Carter [56] \\
\hline & Sa2. We are pleased with what this supplier does for us. & Yilmaz et al. [57] \\
\hline \multirow{3}{*}{ Customer Loyalty } & Lo1. We have a strong sense of loyalty to the supplier. & Ganesan [40] \\
\hline & Lo2. If we had to do it all over again, we would still choose to use this supplier & Yilmaz et al. [57] \\
\hline & Lo3. We expect this supplier to be working with us for a long time. & Lancastre and Lages [55] \\
\hline
\end{tabular}

is to use well-validated measures reported in previous research. All research variables are measured in accordance with the seven-point Likert scale, with "1" means that the degree of agreement is very low, while with " 7 " means that the degree of agreement is very high.

Moreover, the survey instrument was tested for its reliability. The summary statistics (means and standard deviations), Cronbach alpha values and factor loadings values are presented in the Table 3. Internal consistency as indicated by Cronbach's alpha is the most common test for scale reliability found in the literature. Cronbach's alpha values of 0.7 or higher are considered to be acceptable for the scales [50]. Cronbach's alpha was calculated for each of the six constructs. The all values exceeded Nunnally's recommended standard. Coefficients of Cronbach alpha of all constructs were higher than 0.7 . They ranged from 0.710 to 0.916 as shown in Table 3. This indicated that all measurements used in this study have an acceptable reliability.

\section{Findings}

\subsection{Measurement Model}

Structural Equation Modeling (SEM) is used to investigate relations because the variables are not directly able to observe and they are latent variables. SEM is a multi- variate statistical analysis approach used to explain relationship between latent variables by means of correlation between observed variables. SEM approach is performed at two stages as measurement model and structural model. While measurement model measures ability that observed variables represent latent variables, structural model is used for explaining relationship between structures (latent variables). Observed variables are defined as indicators used for measuring latent variables, and they are measured directly. Latent variables are variables that are not directly observed but are rather inferred from observed variables [51].

Confirmatory factor analysis (CFA) is named as measurement model, and results of CFA give an idea that each observed variable is good representative of latent variable which it belongs. Further, CFA shows validity of the measurement model as a whole by means of goodness-of-fit statistics. Using CFA before searching relationship between latent variables is important for that estimated values provided for the measurement model is kept constant within structural model that will be tested, as well as for substituting that measurement model is acceptable [52].

In SEM studies, analyses are performed by using correlation or covariance matrices derived from the raw data instead of the raw data. In analyzing the measurement 
Table 3. Means, standard deviations, and reliability test.

\begin{tabular}{|c|c|c|c|c|}
\hline & Mean & $\begin{array}{c}\text { Standard } \\
\text { Deviation }\end{array}$ & Cronbach's $\alpha$ & $\begin{array}{c}\text { Factor } \\
\text { Loadings }\end{array}$ \\
\hline \multicolumn{5}{|l|}{ Trust } \\
\hline $\operatorname{Tr} 1$ & 5.68 & 1.27 & 0.916 & 0.845 \\
\hline $\operatorname{Tr} 2$ & 5.76 & 1.30 & & 0.920 \\
\hline $\operatorname{Tr} 3$ & 5.83 & 1.24 & & 0.765 \\
\hline \multicolumn{5}{|c|}{ Cooperation } \\
\hline $\mathrm{Co} 1$ & 5.15 & 1.82 & 0.788 & 0.755 \\
\hline $\mathrm{Co} 2$ & 4.72 & 1.85 & & 0.827 \\
\hline $\mathrm{Co} 3$ & 4.64 & 1.76 & & 0.822 \\
\hline \multicolumn{5}{|c|}{ Communication } \\
\hline Com 1 & 4.41 & 1.92 & 0.710 & 0.800 \\
\hline Com2 & 3.99 & 1.95 & & 0.870 \\
\hline \multicolumn{5}{|c|}{ Commitment } \\
\hline $\mathrm{Cm} 1$ & 4.18 & 2.05 & 0.771 & 0.775 \\
\hline $\mathrm{Cm} 2$ & 4.89 & 1.78 & & 0.854 \\
\hline $\mathrm{Cm} 3$ & 4.79 & 1.82 & & 0.798 \\
\hline \multicolumn{5}{|c|}{ Satisfaction } \\
\hline $\mathrm{Sa} 1$ & 5.77 & 1.33 & 0.890 & 0.905 \\
\hline $\mathrm{Sa} 2$ & 5.61 & 1.38 & & 0.765 \\
\hline \multicolumn{5}{|c|}{ Loyalty } \\
\hline Lo1 & 5.38 & 1.52 & 0.843 & 0.895 \\
\hline Lo2 & 5.52 & 1.50 & & 0.840 \\
\hline Lo3 & 5.98 & 1.28 & & 0.766 \\
\hline
\end{tabular}

model, because of continuous and normally distributed data structure, covariance matrices of the observed variables are utilized, and Maximum Likelihood method is preferred [53]. Path diagram of the measurement model consists of 6 latent variables and 16 observed variables loaded to these latent variables. Path diagram of the measurement model is presented in Figure 2.

Here, Trust, Cooperation, Communication Commitment, Satisfaction and Loyalty are latent variables. Three observed variables ( $\operatorname{Tr} 1, \operatorname{Tr} 2$ and $\operatorname{Tr} 3)$ loaded to Trust, three observed variables $(\mathrm{Co} 1, \mathrm{Co} 2$ and $\mathrm{Co} 3)$ loaded to Cooperation, two observed variables (Com1 and Com2) loaded to Communication, three observed variables $(\mathrm{Cm} 1$, $\mathrm{Cm} 2$ and $\mathrm{Cm} 3)$ loaded to Commitment, two observed variables ( $\mathrm{Sa} 1$ and $\mathrm{Sa} 2)$ loaded to Satisfaction, and three observed variables (Lo1, Lo2 and Lo3) are loaded to Loyalty.

According to results of CFA presented in Table 4, the measurement model $\left(\chi^{2}(89)=134.70, p=0.145>0.05\right)$ is appropriate and acceptable as a whole. As shown in Table 4, goodness-of-fit statistics of the measurement model produced acceptable values. Goodness of fit index (GFI) and Comparative fit index (CFI) are respectively 0.91 and 0.97 . AGFI corrected value of GFI according to complexity of the model is 0.86 .

Other test statistics produced with regard to if the model suit to data or not is expected cross validation index (ECVI). Logic of this statistic is that it compares the model which will be tested with interdependence model and specifically saturated model. Interdependence model shows situation that all relationships are limited to zero. Also saturated model, on the contrary, shows situation that all relationships in the model are described. It is expected that ECVI value produced for the model is lower than ECVI value produced for the saturated model. ECVI value for the model is 1.37 , and ECVI value for the saturated model is 1.63 .

\subsection{Structural Model}

After the measurement model produces appropriate values, structural model analysis that hypotheses between latent variables are tested. The structural model is presented in Figure 3. The structural model $\left(\chi^{2}=164.91, \mathrm{df}=\right.$ $103, \mathrm{p}=0.066>0.05)$ produces very good values with regards to goodness-of-fit statistics $\left(\chi^{2} / \mathrm{df}=1.60 ;\right.$ RMSEA $=$ $0.060 ; \mathrm{NFI}=0.96 ; \mathrm{CFI}=0.98 ; \mathrm{GFI}=0.89 ; \mathrm{AGFI}=0.85$; SRMR $=0.069$ )

When hypotheses results, that relationships between latent variables are tested, are investigated, paths of cooperation-satisfaction satisfaction (estimate $=-1.89$, C.R. $<$ 1.96) and communication-satisfaction (estimate $=0.45$, C.R. $<1.96)$ are found insignificant. Information showing statistically significant levels of hypotheses is presented in Table 5.

Because Hypotheses of $\mathrm{H} 2$ and $\mathrm{H} 3$ are insignificant, these paths should be removed from the model or an alternative model with these latent variables should be developed. To develop an alternative model, either the literature or mediation tests can be utilized.

Latent variables are variables which are related with each other but independent, and they are structures believed to be in theoretical world. At stage of alternative model development, therefore, investigation of correlation level between latent variable is importantt in order to develop a model supported by data. Correlations between latent variables are presented in Table 6, and it is seen that relationship between communication and satisfaction is insignificant. Therefore H3 hypothesis is statistically insignificant and it is rejected.

While developing an alternative model, correlation between latent variables as well as mediation test should be 


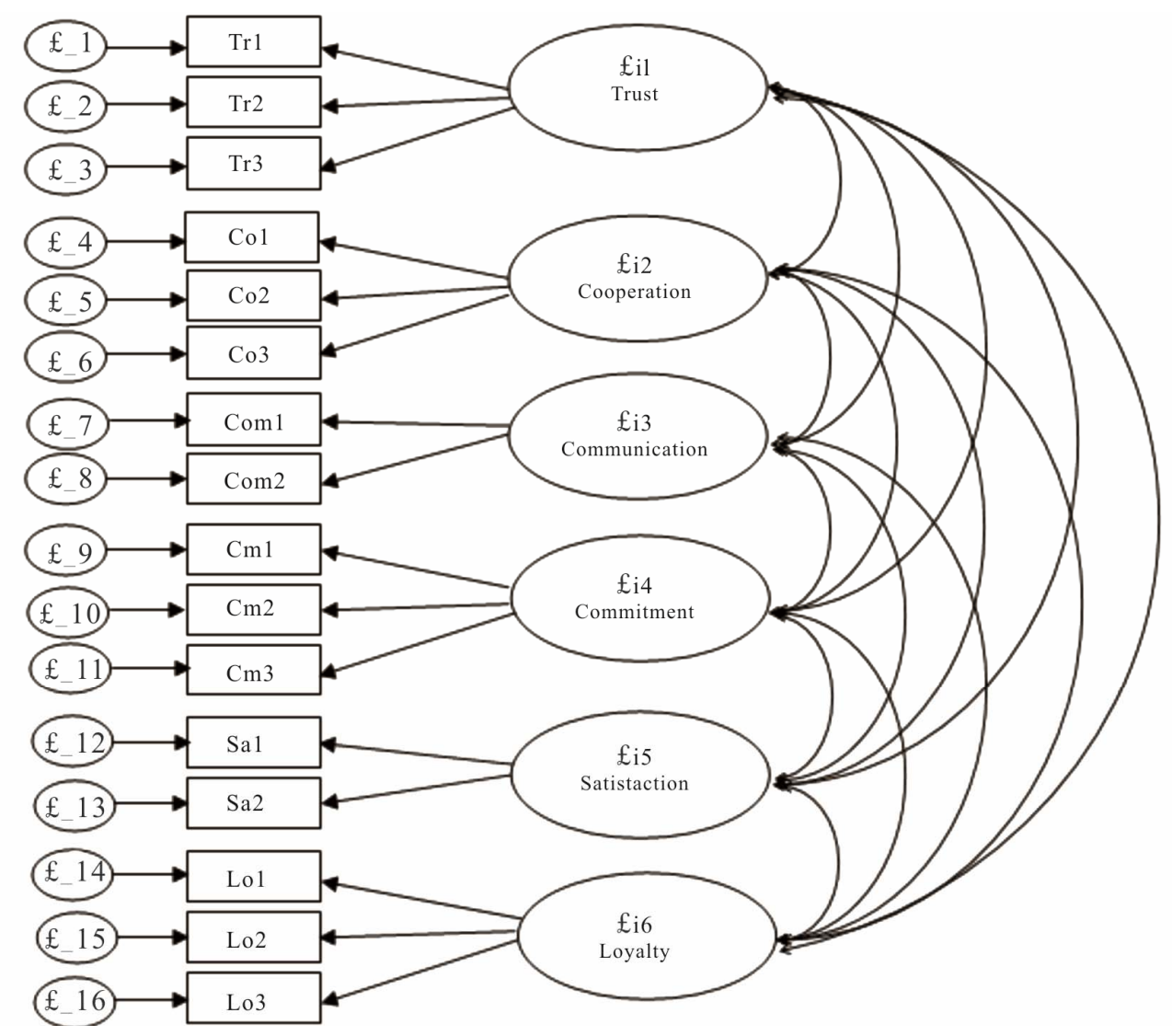

Figure 2. Path diagram of the measurement model.

Table 4. Result of measurement model.

\begin{tabular}{|c|c|c|c|c|c|}
\hline Latent Variable & Observed Variable & Std Factor Loading & Std Error & Critical Ratio & $\mathrm{R}^{2}$ \\
\hline \multirow[t]{3}{*}{ Trust } & $\operatorname{Tr} 1$ & 0.88 & 0.079 & 14.09 & 0.77 \\
\hline & $\operatorname{Tr} 2$ & 0.87 & 0.081 & 13.97 & 0.76 \\
\hline & $\operatorname{Tr} 3$ & 0.91 & 0.075 & 15.16 & 0.84 \\
\hline \multirow[t]{3}{*}{ Cooperation } & $\mathrm{Co} 1$ & 0.68 & 0.13 & 9.27 & 0.46 \\
\hline & $\mathrm{Co} 2$ & 0.81 & 0.13 & 11.74 & 0.65 \\
\hline & $\mathrm{Co} 3$ & 0.74 & 0.12 & 10.46 & 0.55 \\
\hline \multirow[t]{2}{*}{ Communication } & Com1 & 0.80 & 0.20 & 7.74 & 0.64 \\
\hline & Com2 & 0.52 & 0.17 & 5.79 & 0.27 \\
\hline \multirow[t]{3}{*}{ Commitment } & $\mathrm{Cm} 1$ & 0.52 & 0.16 & 6.82 & 0.27 \\
\hline & $\mathrm{Cm} 2$ & 0.88 & 0.11 & 13.76 & 0.78 \\
\hline & $\mathrm{Cm} 3$ & 0.85 & 0.12 & 13.03 & 0.72 \\
\hline \multirow[t]{2}{*}{ Satisfaction } & Sa1 & 0.87 & 0.082 & 13.98 & 0.76 \\
\hline & $\mathrm{Sa} 2$ & 0.92 & 0.083 & 15.39 & 0.85 \\
\hline \multirow[t]{3}{*}{ Loyalty } & Lo1 & 0.86 & 0.097 & 13.27 & 0.73 \\
\hline & Lo2 & 0.84 & 0.083 & 12.84 & 0.70 \\
\hline & Lo3 & 0.72 & 0.11 & 10.38 & 0.52 \\
\hline
\end{tabular}




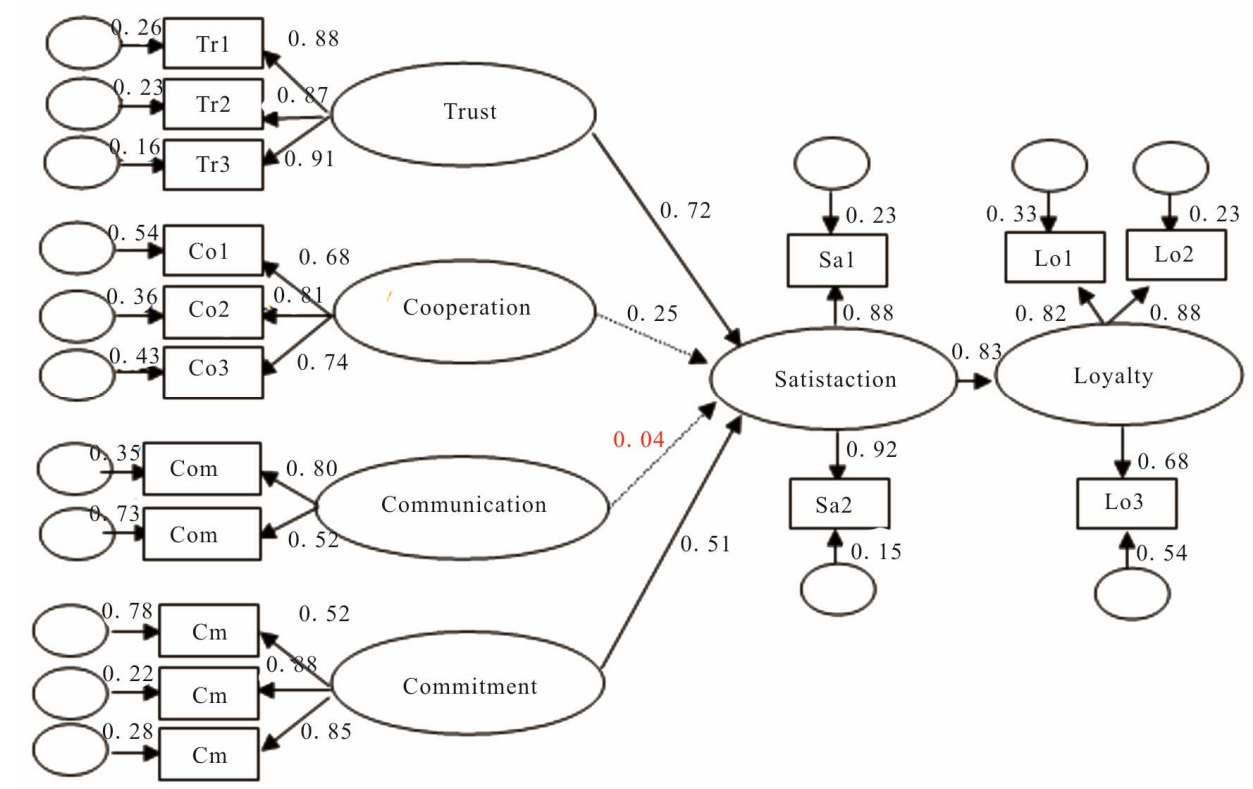

Figure 3. The structural model.

Table 5. Result of measurement model.

\begin{tabular}{lllll}
\hline Hypothesis & Hypothesized path & Path coefficient & Critical Ratio & Results \\
\hline H1 & Trust $\rightarrow$ Satisfaction & 0.72 & 11.22 & Supported \\
H2 & Cooperation $\rightarrow$ Satisfaction & 0.25 & 1.89 & Not \\
H3 & Communication $\rightarrow$ Satisfaction & 0.04 & 0.45 & Not \\
H4 & Commitment $\rightarrow$ Satisfaction & 0.51 & 6.09 & Supported \\
H5 & Satisfaction $\rightarrow$ Loyalty & 0.83 & 13.92 & Supported \\
\hline
\end{tabular}

Table 6. Correlations between latent variables.

\begin{tabular}{|c|c|c|c|c|c|c|}
\hline & 1 & 2 & 3 & 4 & 5 & 6 \\
\hline Satisfaction (1) & 1 & & & & & \\
\hline Loyalty (2) & $0.84^{* *}$ & 1 & & & & \\
\hline Trust (3) & $0.86^{* *}$ & $0.76^{* *}$ & 1 & & & \\
\hline Cooperation (4) & $0.50^{* *}$ & $0.60^{* *}$ & $0.55^{* *}$ & 1 & & \\
\hline Communication (5) & 0.20 & $0.35^{* *}$ & $0.23^{*}$ & $0.67^{* *}$ & 1 & \\
\hline Commitment (6) & $0.75^{* *}$ & $0.57^{* *}$ & $0.54^{* *}$ & $0.70^{* *}$ & $0.37^{* *}$ & 1 \\
\hline
\end{tabular}

${ }^{* *}$ Correlation is significant at the 0.01 level (2-tailed); ${ }^{*}$ Correlation is significant at the 0.05 level (2-tailed).

examined. During development of an alternative model, the theoretical reasons for the changes made to the model must be put out.

In the current model, satisfaction variable is a mediation variable between exogenous variables (trust, cooperation, communication, commitment) and latest latent variable of Loyalty. Therefore, effects of four exogenous variables are transferred indirectly through satisfaction to loyalty.

Because paths from Cooperation and Communication to Satisfaction are insignificant, relationships of these two variables with loyalty should be review. Therefore, direct paths from these two variables to loyalty are drawn and then it is researched if there are direct effects of 
cooperation and communication, supported by data set, on Loyalty. Thus the model is retest. At the end of the analyses direct effect of cooperation on loyalty also found as insignificant. But when effect from communication to loyalty is added to model as direct effect, all paths within the model are found as statistically significant, and at the end, the model is transformed to an acceptable model with regards to goodness-of-fit values.

Alternative model created as a result of mediation tests is presented in Figure 4. As shown in Figure 4, effects of Trust, Cooperation, and Commitment on Loyalty are transported via Satisfaction. But Communication has a direct effect on Loyalty.

Produced goodness of fit statistics show that provided alternative model is supported by the data. Goodnessof-fit index (GFI) is found as 0.93; Adjusted Goodnessof-fit index (AGFI) is found as 0.89; normed Chi-Square $\left(\chi^{2} / \mathrm{df}\right)$ is found as 1.52 ; comparative fit index (CFI) is found as 0.96 , and root-mean-square error of approximation (RMSEA) is found as 0.056 . Summary information related structural model is presented in Table 7.

\section{Discussion}

This paper investigates manufacturer - supplier relationships in metal manufacturing industry in Turkey and tests the measurement and structural features of a model where trust, cooperation and commitment are positive precursors to satisfaction; satisfaction and communication is a positive precursor to loyalty. The models have acceptable fits, validity, and reliability of both the measurement and structural properties. Furthermore, the re- sults support four hypothesized relationships in the conceptual model. But communication is not precursor to satisfaction; it is a positive precursor to loyalty. Therefore the results don't support one hypothesized relationship.

In this study, selected dimensions are actually most studied in the literature. This could diminish the potential contribution of the study. But, while most of the studies about $\mathrm{b} 2 \mathrm{~b}$ relations, satisfaction and loyalty were generally performed in developed countries, this study is carried out in an emerging country. Therefore, the most important contribution of this research is to investigate buyer-supplier relationships in an emerging country, Turkey.

The outcome of the study includes a significant positive relationship between trust, commitment and customer satisfaction, and a significant relationship between cooperation and satisfaction, as well as an indirect relationship (via customer satisfaction) between trust, commitment, cooperation and loyalty, a direct relationship between communication and loyalty, a direct relationship between satisfaction and loyalty. These findings are useful in understanding the subjects of buyer-supplier relations, customer satisfaction and loyalty. Significant relationship between cooperation and satisfaction is consistent with studies such as Narus [39], Ganesan [40], Mohr and Speakman [41]. Also, as consistent with the studies such as Hesket el al. [31], Rauyren and Miller [7], Selnes and Gonhaug [30] satisfaction has positive and signifycant effect on loyalty. As a result, this study makes a contribution to both theory and practice in the field of

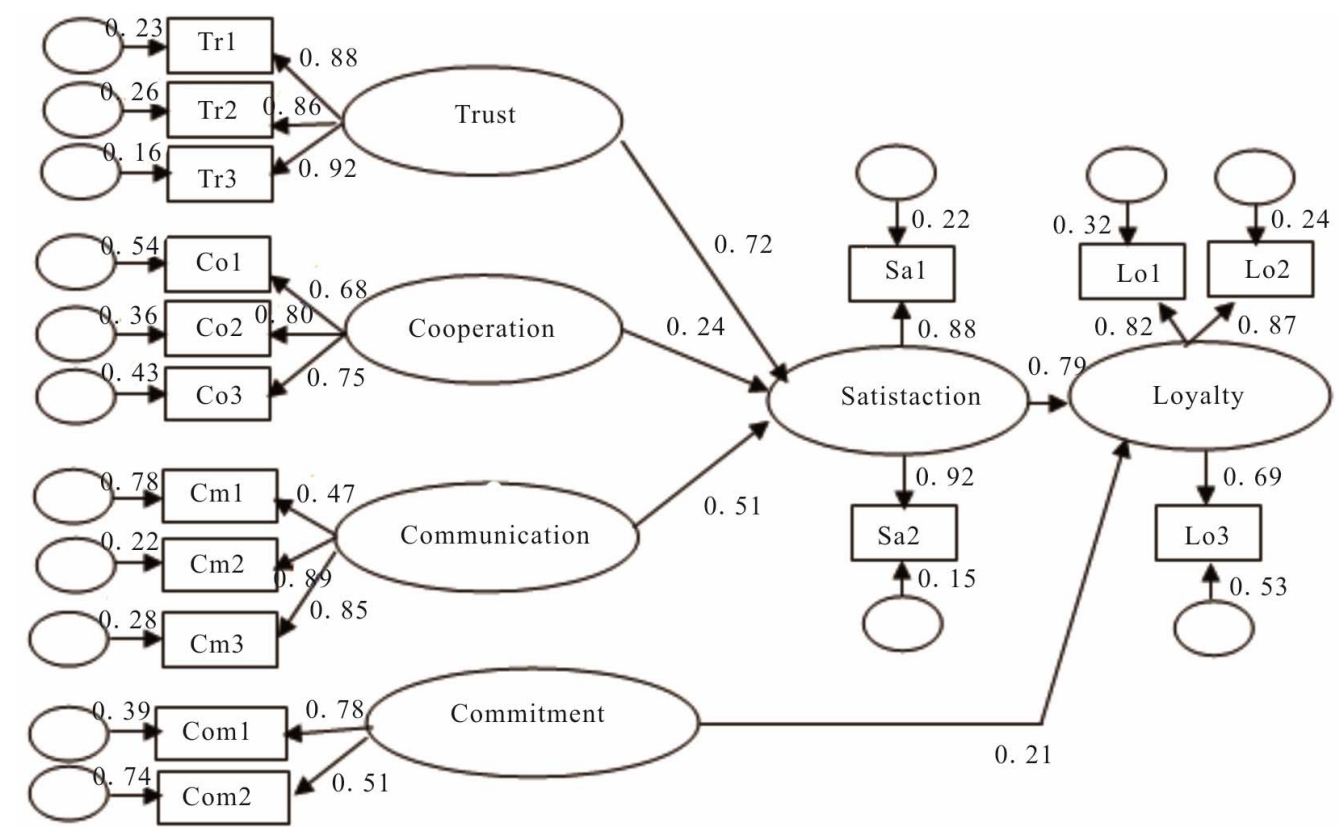

Figure 4. Alternative (Final) structural model. 
Table 7. Result of final structural equation model.

\begin{tabular}{lllll}
\hline \multirow{2}{*}{ Paths } & \multicolumn{4}{l}{ Results } \\
\cline { 2 - 5 } & Estimate & S.E. & C.R. & P \\
\hline Trust $\rightarrow$ Satisfaction & 0.72 & 0.062 & 11.88 & 0.000 \\
Cooperation $\rightarrow$ Satisfaction & 0.24 & 0.060 & 2.90 & 0.008 \\
Commitment $\rightarrow$ Satisfaction & 0.51 & 0.068 & 6.44 & 0.000 \\
Communication $\rightarrow$ Loyalty & 0.21 & 0.052 & 2.96 & 0.005 \\
Satisfaction $\rightarrow$ Loyalty & 0.79 & 0.110 & 12.94 & 0.000 \\
\hline
\end{tabular}

S.E.-Standard Error (estimate of the standard error of the covariance); C.R.Critical Ratio ( $t$ values).

b2b relationship. Also, the study tests the measurement and structural effects of the proposed conceptual model on the behalf of other researchers. According to Farrelly and Questar [46] trust and commitment are key factors of satisfaction. Findings of this study, positive and significant effects of trust and commitment on customer satisfaction, support this situation. Contrary to the expected mediation by satisfaction, direct effect of communication on loyalty can be of particular interest especially in the context of a developing country. Also the study shows results of managerial attention. Specifically, managers would utilize the knowledge that trust and commitment are a key factor for customer satisfaction and communication is very important for customer loyalty.

Despite the contributions of this study it has some research limitations. First, the sample in this study includes only small and medium-sized firms in Turkey except seven companies. This may decrease the generalization ability of findings for larger firms and for firms in other countries. Another limitation of the study that only one individual from respondent firm provided information on all of dimensions. Other limitation is the model contains only four dimensions of relations, not cover all dimensions. Also the study only tests the relationship between manufacturers and suppliers, not all b2b relations. For future research, validity of the findings should be investtigated through studies in other industries and other countries. Other dimensions of relationship should be included to the model of the study such as knowledge sharing, power, autonomy, conflict, adoption etc. Their effects should be investigated on the satisfaction and loyalty.

\section{REFERENCES}

[1] T. O'Toole and B. Donaldson, "Relationship Performance Dimensions of Buyer-Supplier Exchanges," European Journal of Purchasing and Supply Management, Vol. 8, No. 3, 2002, pp. 197-207.

\section{doi:10.1016/S0969-7012(02)00008-4}

[2] D. Skarmeas, C. S. Katisikeas, S. Spyropoulou and E. Salehi-Sangari, "Market and Supplier Characteristics Driving Distributor Relationship Quality in International Marketing Channels of Industrial Products," Industrial Marketing Management, Vol. 37, No. 1, 2008, pp. 23-36. doi:10.1016/j.indmarman.2007.04.004

[3] T. Minahan, "Is Partnering a Sham?" Purchasing, Vol. 12, No. 2, 1998, pp. 61-64.

[4] F. T. S. Chan, "Interactive Selection model for Supplier Selection Process: An Analytical Hierarchy Process Approach," International Journal of Production Research, Vol. 41, No. 15, 2003, pp. 3549-3579. doi: $10.1080 / 0020754031000138358$

[5] C. Sanchez-Rodriguez, D. Hemsworth and A. R. Martinez-Lorente, "The Effect of Supplier Development Initiatives on Purchasing Performance: A Structural Model," Supply Chain Management: An International Journal, Vol. 10, No. 4, 2005, pp. 289-301.

[6] A. G. Abdul-Mumin, "Instrumental and Interpersonal Determinants of Relationship Satisfaction and Commitment in Industrial Markets," Journal of Business Research, Vol. 58, No. 5, 2005, pp. 619-628. doi:10.1016/j.jbusres.2003.08.004

[7] P. Rauyruen and K. E. Miller, "Relationship Quality as a Predictor of b2b Customer Loyalty," Journal of Business Research, Vol. 60, No. 1, 2007, pp. 21-31.

doi:10.1016/j.jbusres.2005.11.006

[8] Wikipedia, Free Encyclopedia, 2012. www.wikipedia.org

[9] S. Ganesan, "Determinants of Long-Term Orientation in buyer-Seller Relationships," Journal of Marketing, Vol. 58, No. 2, 1994, pp. 1-19. doi:10.2307/1252265

[10] D. C. Bello, R. Lohtia and S. P. Dant, "Collaborative Relationships for Component Development: The Role of Strategic Issues, Production Costs, and Transaction Costs," Journal of Business Research, Vol. 45, No. 1, 1999, pp. 15-31. doi:10.1016/S0148-2963(98)00006-X

[11] K. Hewett, R. B. Money and S. Sharma, "An Exploration of the Moderating Role of Buyer Corporate Culture in Industrial Buyer-Seller Relationships," Journal of the Academy of Marketing Science, Vol. 30, No. 3, 2002, pp. 229-239.

[12] J. P. Cannon and C. Homburg, "Buyer-Supplier Relationships and Customer Firm Costs," Journal of Marketing, Vol. 65, No. 1, 2001, pp. 9-43.

[13] Y. Theodorakioglou, K. G. Theodorakioglou and G. Tsiolvas, "Supplier Management and Its Relationship to Buyers' Quality Management," Supply Chain Management: An International Journal, Vol. 11, No. 2, 2006, pp. 148-159. doi:10.1108/13598540610652546

[14] A. Walter, T. Muller, G. Helfert and T. Ritter, "Functions of Industrial Supplier Relationships and Their Impact on Relationship Quality," Industrial Marketing Management, Vol. 2, 2003, pp. 159-169. doi:10.1016/S0019-8501(02)00230-4

[15] F. Selnes, "Antecedents and Consequences of Trust and 
Satisfaction in Buyer-Seller Relationships," European Journal of Marketing, Vol. 32, No. 3-4, 1998, pp. 305322. doi:10.1108/03090569810204580

[16] P. Jonsson and M. Zineldin, "Achieving High Satisfaction in Supplier-Dealer Working Relationship," Supply Chain Management: An International Journal, Vol. 8, No. 3, 2003, pp. 224-250. doi:10.1108/13598540310484627

[17] G. P. Dapiran and S. Hogarth-Scott, "Are Cooperation and Trust Being Confused with Power? An Analysis of Food Retailing in Australia and the UK," International Journal of Retail and Distribution Management, Vol. 1, No. 2, 2003, pp. 256-267. doi:10.1108/09590550310472424

[18] K. Wo and C. T. Ennew, "Business-To-Business Relationship Quality an IMP Interaction-Based Conceptualization and Measurement," European Journal of Marketing, Vol. 38, No. 9-10, 2004, pp. 1252-1271. doi:10.1108/03090560410548960

[19] C. Terawatanavong and A. Quazi, "Conceptualising the Link between National Cultural Dimensions and B2B Relationships," Asia Pacific Journal of Marketing and Logistics, Vol. 18, No. 3, 2006, pp. 173-183. doi:10.1108/13555850610675643

[20] H. Vasudevan, S. S. Gaur and R. K. Shide, "Relational Switching Costs, Satisfaction and Commitment a Study in the Indian Manufacturing Context," Asia Pacific Journal of Marketing and Logistics, Vol. 18, No. 4, 2006, pp. 342-353. doi:10.1108/13555850610703281

[21] C. Terawatanavong, G. J. Whitwel and R. E. Widing, "Buyer Satisfaction with Relational Exchange across the Relationship Lifecycle," European Journal of Marketing, Vol. 41, No. 7-8, 2007, pp. 915-938. doi:10.1108/03090560710752456

[22] R. P. J. Kingshott and A. Pecotich, "The Impact of Psychological Contracts on Trust and Commitment in Supplier-Distributor Relationships," European Journal of Marketing, Vol. 41, No. 9-10, 2007, pp. 1053-1072. doi:10.1108/03090560710773345

[23] N. G. Rodríguez, M. J. S. Perez and J. A. T. Gutierrez, "Interfunctional Trust as a Determining Factor of a New Product Performance," European Journal of Marketing, Vol. 41, No. 5-6, 2007, pp. 678-702. doi:10.1108/03090560710737688

[24] S. Kabaday1 and S. Ryu, "The Protection of the Trustor through the Use of Control Mechanisms and Its Performance Implications," Journal of Business and Industrial Marketing, Vol. 22, No. 4, 2007, pp. 260-271. doi:10.1108/08858620710754522

[25] J. Chung, B. Sternquist and Z. Chen, "Japanese RetailBuyer-Supplier Relationships: Does Performance Matter?" Asia Pacific Journal of Marketing and Logistics, Vol. 20, No. 1, 2008, pp. 55-75. doi: $10.1108 / 13555850810844878$

[26] G. Svensson, T. Mysen and J. Payan, "Balancing the Sequential Logic of Quality Constructs in ManufacturingSupplier Relationships - Causes and Outcomes," Journal of Business Research, Vol. 63, No. 11, 2010, pp. 1209-
1214. doi:10.1016/j.jbusres.2009.10.019

[27] N. J. Bharadwaj and K. Matsuno, "Investigating the Antecedents and Outcomes of Customer Firm Transaction Cost Savings in a Supply Chain Relationship," Journal of Business Research, Vol. 59, 2006, pp. 62-72. doi:10.1016/i.jbusres.2005.03.007

[28] K. Kim, I. Jeong, J. Park, Y. Park, C. Kim and T. Kim, "The Impact of Network Service Performance on Customer Satisfaction and Loyalty: High-Speed Internet Service Case in Korea," Expert Systems with Applications, Vol. 32, No. 3, 2007, pp. 822-831. doi:10.1016/j.eswa.2006.01.022

[29] K. Eriksson and L. A. Vaghult, "Customer Retention, Purchasing Behavior and Relationship Substance in Professional Services," Industrial Marketing Management, Vol. 29, No. 4, 2000, pp. 363-732. doi:10.1016/S0019-8501(00)00113-9

[30] F. Selnes and K. Gonhaug, "Effects of Supplier Reliability and Benevolence in Business Marketing," Journal of Business Research, Vol. 49, No. 3, 2000, pp. 259-271. doi:10.1016/S0148-2963(99)00017-X

[31] J. L. Heskett, W. E. Sasser and L. A. Schlesinger, "The Service Profit Chain: How Leading Companies Link Profit and Growth to Loyalty, Satisfaction, and Value,' Trans. Free Press., New York, 1997.

[32] C. Moorman, G. Zaltman and R. Deshpande, "Relationships between Providers and Users of Marketing Research: The Dynamics of Trust within and between Organizations," Journal of Marketing Research, Vol. 29, 1992, pp. 314-329.

[33] T. Gao, M. J. Sirgy and M. M. Bird, "Reducing Buyer Decision-Making Uncertainty in Organizational Purchasing: Can Supplier Trust, Commitment, and Dependence Help?" Journal of Business Research, Vol. 58, No. 4, 2005, pp. 397-405. doi:10.1016/S0148-2963(03)00137-1

[34] D. McCutcheon and F. I. Stuart, "Issues in the Choice of Supplier Alliance Partners," Journal of Operations Management, Vol. 18, No. 3, 2000, pp. 279-301.

[35] H. Ma, "Toward Global Competitive Advantage. Creation, Competition, Cooperation, and Co-Option," Management Decision, Vol. 42, No. 7, 2004, pp. 907-924. doi:10.1108/00251740410550961

[36] C. Prahinski and W. C. Benton, "Supplier Evaluations: Communication Strategies to Improve Supplier Performance," Journal of Operations Management, Vol. 22, No. 1, 2004, pp. 39-62. doi:10.1016/i.jom.2003.12.005

[37] R. Derocher and J. Kilpatrick, "Six Supply Chain Lessons for the New Millennium," Supply Chain Management Review, Vol. 3, No. 4, 2000, pp. 34-41.

[38] C. R. Moberg and T. W. Speh, "Evaluating the Relationship between Queationable Practices and the Strength of Supply Chain Relationships," Journal of Business Logistics, Vol. 24, No. 2, 2003, pp. 1-19. doi:10.1002/j.2158-1592.2003.tb00043.x

[39] J. C. Anderson and J. A. Narus, "A Model of Distributor Firm and Manufacturer Firm Working Partnerships," 
Journal of Marketing, Vol. 54, No. 1, 1990, pp. 42-58. doi: $10.2307 / 1252172$

[40] S. Ganesan, "Determinants of Long-Term Orientation in Buyer-Seller Relationships," Journal of Marketing, Vol. 58, No. 2, 1994, pp. 1-19. doi:10.2307/1252265

[41] J. Mohr and R. Spekman, "Characteristics of Partnership Success: Partnership Attributes," Supply Chain Management: An International Journal, Vol. 11, No. 2, 1994, pp. 148-159.

[42] P. M. Doney, J. M. Barry and R. Abratt, "Trust Determinants and Outcomes in Global B2B Services," European Journal of Marketing, Vol. 41 No. 9-10, 2007, pp. 10961116. doi:10.1108/03090560710773363

[43] R. M. Morgan and S. D. Hunt, "The Commitment-Trust Theory of Relationship Marketing," Journal of Marketing, Vol. 58, No. 3, 1994, pp. 20-38. doi:10.2307/1252308

[44] S. D. Jap and S. Ganesan, "Control Mechanisms and the Relationship Lifecycle: Implications for Safeguarding Specific Investments and Developing Commitment," Journal of Marketing Research, Vol. 37, No. 2, 2000, pp. 227245. doi:10.1509/jmkr.37.2.227.18735

[45] Y. Liu, Y. Li and J. Xue, "Transfer of Market Knowledge in a Channel Relationship: Impacts of Attitudinal Commitment and Satisfaction," Industrial Marketing Management, Vol. 39, No. 2, 2010, pp. 229-239. doi:10.1016/j.indmarman.2008.12.017

[46] F. J. Farrelly and P. G. Quester, "Examining Important Relationship Constructs of the Focal Sponsorship Exchange," Industrial Marketing Management, Vol. 34, No. 3, 2005, pp. 211-219. doi:10.1016/j.indmarman.2004.09.003

[47] ISO, "ISO V. Sanayi Kongresi Basın Bülteni," 2011. http://www.demirdokum.com.tr/haberler/haberler.aspx?S ectionId=76andContentId $=464$

[48] B. Metal, "Iron-Steel Industry," United Metal Workers' Union, 2003. http://birlesikmetal.org/kitap/kitap_03/2003-2.pdf

[49] KOSANO, "Kocaeli Sanayisi," Kocaeli Chamber of Industry, 2011. www.kosano.org.tr

[50] J. C. Nunnally, "Psychometric Theory," 2nd Edition, McGraw-Hill, New York, 1978.

[51] K. A. Bollen, "Structural Equations with Latent Variables," Wiley Publication, New York, 1989.

[52] R. B. Kline, "Principles and Practice of Structural Equation Modeling," 2nd Edition, The Guilford Press, New York, 2005.

[53] W. H. Tsai, W. C. Chou and C. W. Lai, "An Effective Evaluation Model and Improvement Analysis for National Park Websites: A Case Study of Taiwan," Tourism Management, Vol. 31, No. 6, 2010, pp. 936-952 doi:10.1016/i.tourman.2010.01.016

[54] P. K. Humphreys, W. L. Li and L. Y. Chan, "The Impact of Supplier Development on buyer-Supplier Performance," Omega, Vol. 32, No. 2, 2004, pp. 131-143. doi:10.1016/j.omega.2003.09.016

[55] A. Lancastre and L. F. Lages, "The Relationship between Buyer and a B2B E-Marketplace: Cooperation Determinants in an Electronic Market Context," Industrial Marketing Management, Vol. 35, No. 6, 2006, pp. 774-789. doi:10.1016/j.indmarman.2005.03.011

[56] C. R. Carter, "Ethical Issues in International Buyer-Supplier Relationships: A Dyadic Examination," Journal of Operations Management, Vol. 18, No. 2, 2000, pp. 191208. doi:10.1016/S0272-6963(99)00016-9

[57] C. Yilmaz, B. Sezen and E. T. Kabaday1, "Supplier Fairness as a Mediating Factor in the Supplier PerformanceReseller Satisfaction Relationship," Journal of Business Research, Vol. 57, No. 8, 2004, pp. 854-886. doi:10.1016/S0148-2963(02)00485-X 